\title{
THE DEVELOPMENT OF FLY ASH - RED MUD BASED GEOPOLYMER
}

\author{
${ }^{1}$ Gábor Mucsi, ${ }^{2}$ Roland Szabó, ${ }^{3}$ Mária Ambrus, ${ }^{4}$ Balázs Kovács \\ ${ }^{1-3}$ University of Miskolc, Miskolc-Egyetemváros, 3515, Miskolc, Hungary, \\ 1e-mail: ejtmucsi@uni-miskolc.hu \\ 2e-mail: ejtszabor@uni-miskolc.hu \\ 3 e-mail: ontam@uni-miskolc.hu \\ ${ }^{4}$ Envirotis Ltd, 2890, Tata, Hungary, \\ kovacs.balazs@envirotis.hu
}

\begin{abstract}
Taking into account environmental considerations, such as decreasing $\mathrm{CO}_{2}$ emission and the ecological footprint, the utilisation of secondary raw materials is essential for sustainable development. Fly ash is the product of coal combustion plants that is collected by various air cleaning equipment from flue gas, and red mud is the by-product of the Bayer-process, through which alumina can be produced from bauxite. Geopolymerisation is a process that is suitable for the utilisation of such wastes to produce ceramics, cement, concrete etc. with many advantageous properties.

The main objective of the article is to present data on the development and examination of geopolymer made out of deposited fly ash from Tatabánya and red mud from Almásfüzitö.

During the experiments, red mud was added to previously optimised fly ash geopolymer in various quantities and compressive strength tests were carried out to determine the optimal fly ash and red mud ratio. However, as the cracking of the specimens could be observed, further tests were carried out on the durability of the geopolymers. The effect of the sealing conditions and RM calcination was investigated, both via visual inspection and with FT-IR analysis at the ages of $3,7,14,28$ and 90 days.

Based on the results, it could be concluded that the sealing conditions have direct effect on the structural characteristics of fly ash - red mud based geopolymers, but further experiments should be carried out for the identification of the ongoing reactions.
\end{abstract}

Keywords: geopolymer, fly ash, FT-IR, red mud

\section{INTRODUCTION}

Geopolymers are inorganic polymers synthesized by the reaction of alumino-silicate and alkali compounds at ambient or near ambient temperature. As certain industrial wastes, such as fly ash, blast furnace slag and mine tailings contain sufficient amounts of reactive alumina and silica, they can be used as raw materials for geopolymerization. Therefore, geopolymerization can be considered a viable technology to transform industrial wastes into utilisable materials. Furthermore, geopolymers possess excellent physico-chemical and mechanical properties, e.g. low density, high strength, thermal stability, fire and chemical resistance. Thus, many industrial applications are viable in the areas of construction, road building, mining, metallurgy etc $[1,2,3,4,5]$.

Fly ash is an industrial waste produced by coal-fired power plants and collected during flue gas cleaning, i.e. with filter bags, electrostatic separators etc. Its main constituents are $\mathrm{SiO}_{2}$ and $\mathrm{Al}_{2} \mathrm{O}_{3}$, but other minor components can be frequently found in it as well, e.g. $\mathrm{CaO}, \mathrm{Fe}_{2} \mathrm{O}_{3}, \mathrm{MgO}$ etc. [6, 7]. Red mud is the byproduct of the Bayer-process, through which alumina can be produced from bauxite ore. It is a highly alkaline material, $11.3 \pm 1.0 \mathrm{pH}$, with high moisture and very fine particle size. The main constituents include $\mathrm{Fe}_{2} \mathrm{O}_{3}, \mathrm{Al}_{2} \mathrm{O}_{3}, \mathrm{SiO}_{2}, \mathrm{CaO}, \mathrm{Na}_{2} \mathrm{O}, \mathrm{TiO}_{2}, \mathrm{~K}_{2} \mathrm{O}$ and $\mathrm{MgO}$ [7, 8].

The aim of the experiments was to develop geopolymer with the synergic use of fly ash and red mud, and to examine its properties and durability. 


\section{MATERIALS AND METHODS}

The main solid raw materials were landfilled brown coal fly ash (FA) from Tatabánya and red mud (RM) from Almásfüzitő. The particle size distribution of FA and RM was examined with a Horiba LA950 V2 type laser particle size analyser. The particle size distribution of both solid raw materials can be observed in Fig. 1. The median particle size of the FA was $\mathrm{x}_{50}=24.28 \mu \mathrm{m}$ and $\mathrm{x}_{50}=3.09 \mu \mathrm{m}$ for the RM.

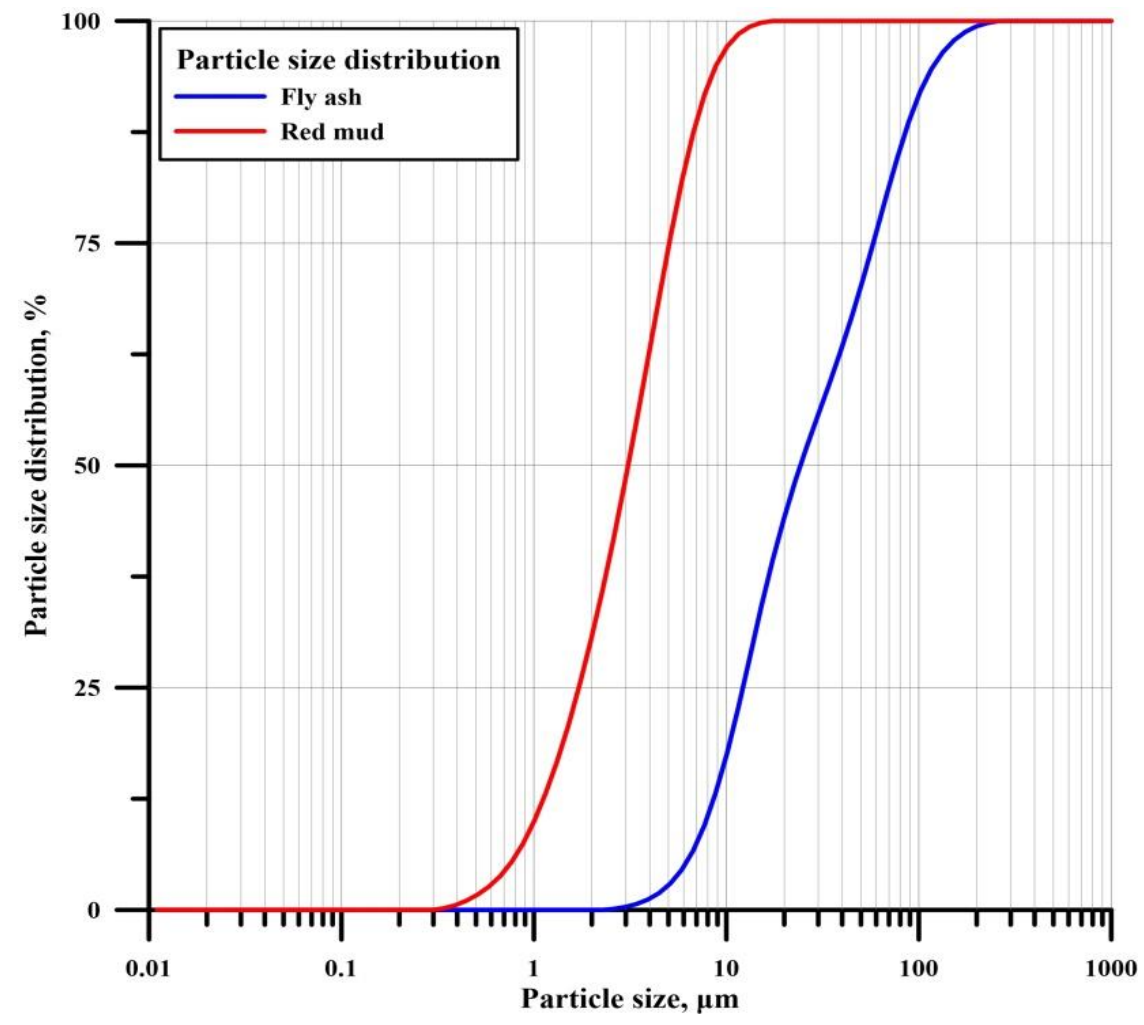

Figure 1. The particle size distributions of the fly ash and red mud samples

The moisture content of the FA samples was $28.80 \%$, and the ignition loss was $0.75 \%$. Based on the XRF analysis, the main oxidic components were $\mathrm{SiO}_{2}$ (46.40\%), $\mathrm{Al}_{2} \mathrm{O}_{3}(27.40 \%), \mathrm{Fe}_{2} \mathrm{O}_{3}(6.96 \%), \mathrm{CaO}(7.04 \%)$, $\mathrm{MgO}(2.23 \%), \mathrm{K}_{2} \mathrm{O}(1.65 \%)$ and $\mathrm{TiO}_{2}(0.94 \%)$. The FA was first oven dried at $105{ }^{\circ} \mathrm{C}$ and then mechanically activated, i.e. ground for 10 minutes in a $\varnothing 305 \times 305 \mathrm{~mm}$ ball mill.

The moisture content of the RM was $38.16 \%$. After oven-drying at $105^{\circ} \mathrm{C}, \mathrm{RM}$ was pulverised in a mortar. For the durability tests, the dried and pulverised $\mathrm{RM}$ was also calcined at $850{ }^{\circ} \mathrm{C}$ for 1 hour.

The mineral composition of RM obtained from the XRD test is summarised in Tab. 1. 
Table 1. The mineral composition of red mud

\begin{tabular}{|l|c|}
\hline Phase & Ratio, wt.\% \\
\hline Hematite & 38.4 \\
\hline Cancrinite $(\mathrm{OH})$ & 25.7 \\
\hline Cancrinite $\left(\mathrm{CO}_{3}\right)$ & 12.1 \\
\hline Katoite & 7.6 \\
\hline Calcite magnesian & 4.9 \\
\hline Gibbsite & 4.2 \\
\hline Boehmite & 0.6 \\
\hline Zircon & 0.4 \\
\hline Amorphous & 6.0 \\
\hline
\end{tabular}

Based on previous experiments [9], the liquid/solid ratio was 0.82 , with $8 \mathrm{M} \mathrm{NaOH}$ solution and Betol SB type water glass used as an activator solution; the composition of the water glass is $\mathrm{SiO}_{2}(25.3 \%), \mathrm{Na}_{2} \mathrm{O}$ $(13.7 \%)$ and $\mathrm{K}_{2} \mathrm{O}(2.7 \%)$.

For geopolymer production, fly ash, red mud and the activator solution was mixed in 5 different ratios and 5 specimens were prepared from each paste. After holding the moulded geopolymer paste under sealed conditions for 24 hours, heat curing was carried out at $50{ }^{\circ} \mathrm{C}$ for $6 \mathrm{~h}$. Then the specimens were left to cool down. After a five-day holding time, uniaxial compressive strength tests were carried out.

A Jasco FT-IR 4200 type Fourier transform infrared spectrometer was used for the structural analyses.

\section{RESULTS AND DISCUSSION}

\subsection{The effect of red mud addition}

At a constant solid matter quantity, fly ash was substituted with $0,5,10,20$ and 40 wt.\% red mud. The obtained average uniaxial compressive strength values and specimen densities are illustrated in Fig. 2.

Without the addition of RM, over $20 \mathrm{MPa}$ average compressive strength values could be achieved which was the highest among the examined mixtures. With the addition of 5, 10 and $20 \mathrm{wt} . \% \mathrm{RM}$, the uniaxial compressive strength decreased but remained around 15-20 MPa. However, the use of 40 wt.\% RM drastically decreased the compressive strength of the specimens, but still reached over $9 \mathrm{MPa}$ 


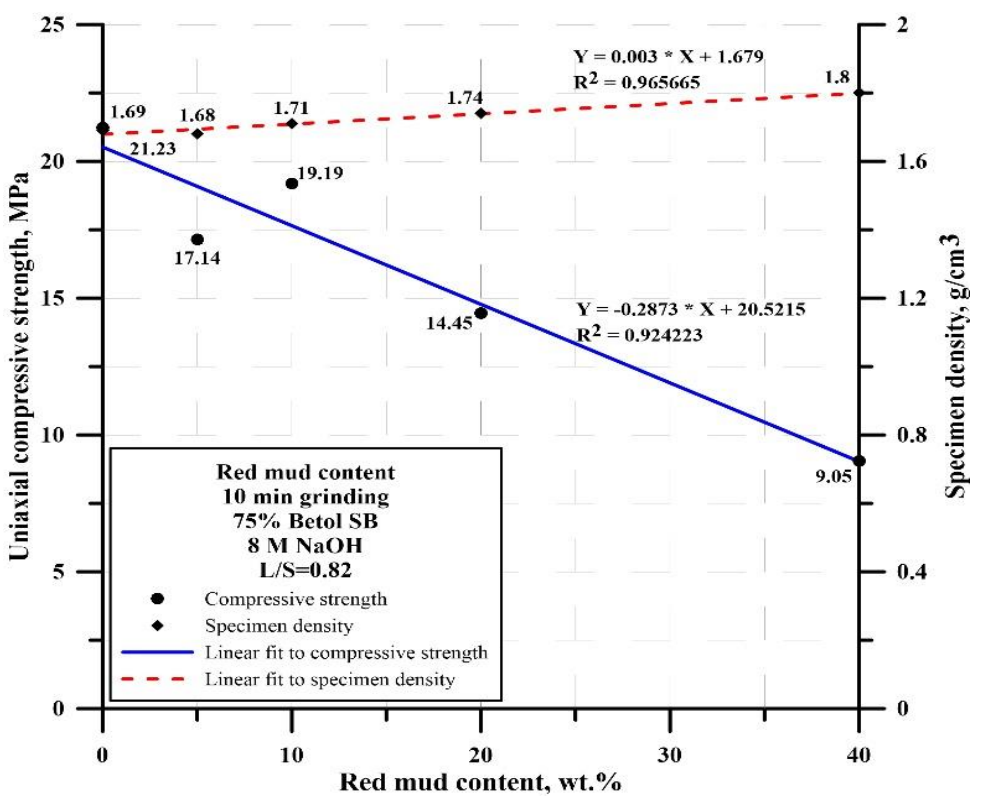

Figure 2. The effect of red mud on the average compressive strength and specimen density

The produced fly ash - red mud geopolymers had similar, or even higher compressive strength values than the geopolymers found in literature, produced under similar circumstances [7, 10 11].

In case of specimen density, the higher the red mud content in the geopolymer paste was, the higher the average specimen densities became.

\subsection{Durability tests}

As the cracking of the 20 and 40 wt.\% RM content specimens could already be observed after the 5-day holding time, next, the durability of the specimens was examined.

Three sets of geopolymers were produced using $20 \mathrm{wt} . \%$ RM to examine the effect of RM preparation and sealing conditions: non-calcined non-sealed red mud geopolymers (RMGs), non-calcined sealed RMGs and calcined sealed RMGs. Visual examination and FT-IR analysis was carried out at the ages of 3, 7, 14, 28 and 90 days. Photos of the specimens at the examined ages can be observed in Tab. 2.

In case of the non-calcined non-sealed RMGs, the cracking of the 3-and 7-day-old specimens could be observed and after 14 days, each specimen was fractured. On the other hand, all the RMGs held under sealed conditions were intact even after 90 days. 


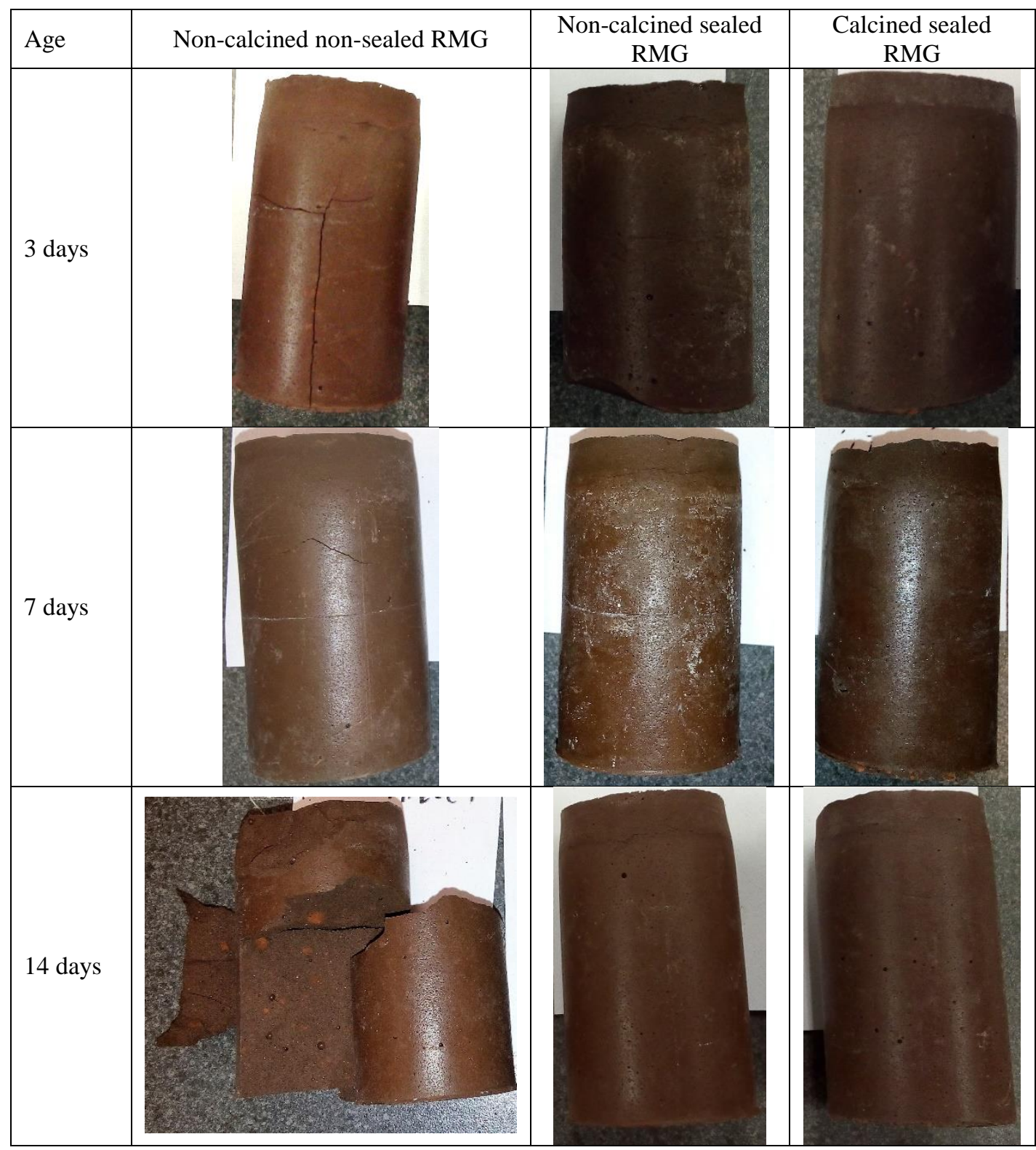




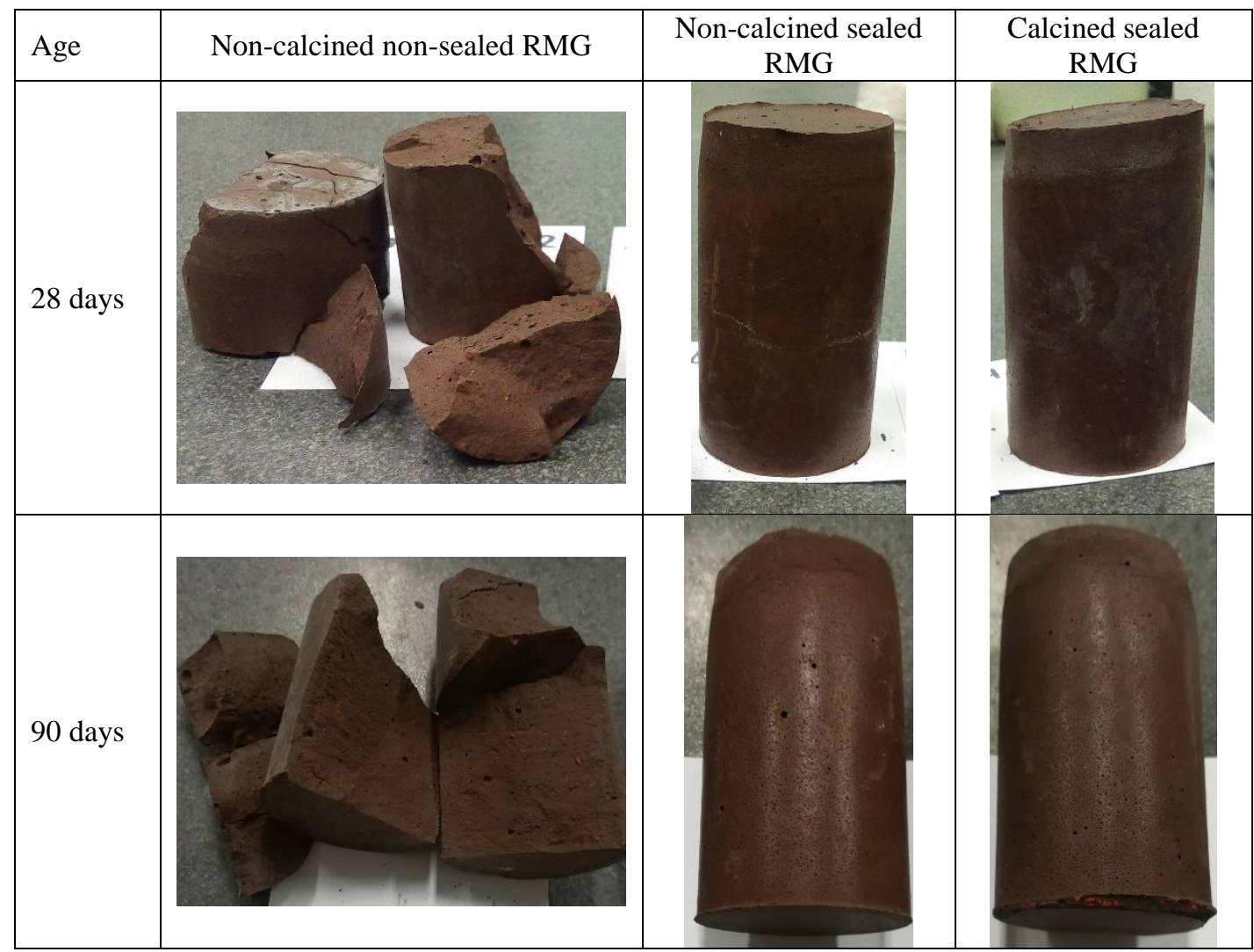

To identify and monitor the structural changes in the geopolymers, FT-IR analysis was carried out after the visual inspection. The wave numbers of the identified peaks and the assigned vibrations are summarised in Tab. 3.

Table 3. The characteristic wave numbers and the assigned vibrations of the RMGs

\begin{tabular}{|l|c|}
\hline Wave number, $\mathrm{cm}^{-1}$ & Vibration \\
\hline $3600-2300$ & stretching $-\mathrm{OH}, \mathrm{HOH}$ \\
\hline $1650-1630$ & bending $\mathrm{HOH}$ \\
\hline $1430-1410$ & stretching O-C-O \\
\hline $1090-990$ & $\begin{array}{l}\text { asymmetric stretching } \\
\text { Si-O-Si and Al-O-Si }\end{array}$ \\
\hline
\end{tabular}

The broad bands in the region between 3600 and $2300 \mathrm{~cm}^{-1}$, i.e. the stretching vibrations of $-\mathrm{OH}$ and $\mathrm{HOH}$, and the peaks between 1650 and $1630 \mathrm{~cm}^{-1}$, i.e. the bending vibration of $\mathrm{HOH}$ groups, are associated with absorbed water on the surface and imprisoned water in the cavities of the specimens. The peaks between 1430 and $1410 \mathrm{~cm}^{-1}$ indicate the stretching vibration of the $\mathrm{O}-\mathrm{C}-\mathrm{O}$ bond of atmospheric carbonation, due to the reaction of $\mathrm{NaOH}$ with atmospheric $\mathrm{CO}_{2}$. Between 1090 and $990 \mathrm{~cm}^{-1}$ the peaks assigned to the asymmetric stretching vibrations of $\mathrm{Si}-\mathrm{O}-\mathrm{Si}$ and $\mathrm{Si}-\mathrm{O}-\mathrm{Al}$ bonds can be found, which are characteristic to geopolymers $[2,4,12,13,14]$. 


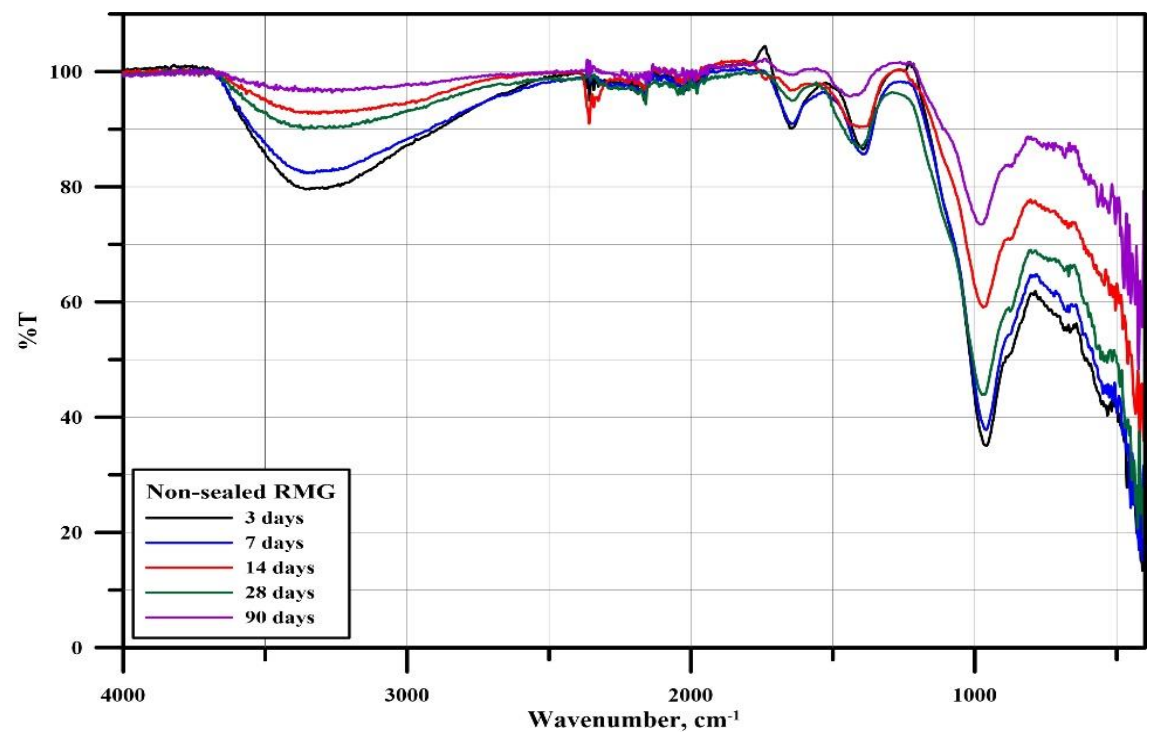

Figure 3. The FT-IR spectra of the non-calcined non-sealed RMG samples

In case of the non-calcined non-sealed RMGs (Fig. 3), the intensity of the peaks continuously decreased until 14 days, but at the age of 28 days, a small increase of each peak could be observed. However, by the 90-day analysis, all peak intensities lessened.

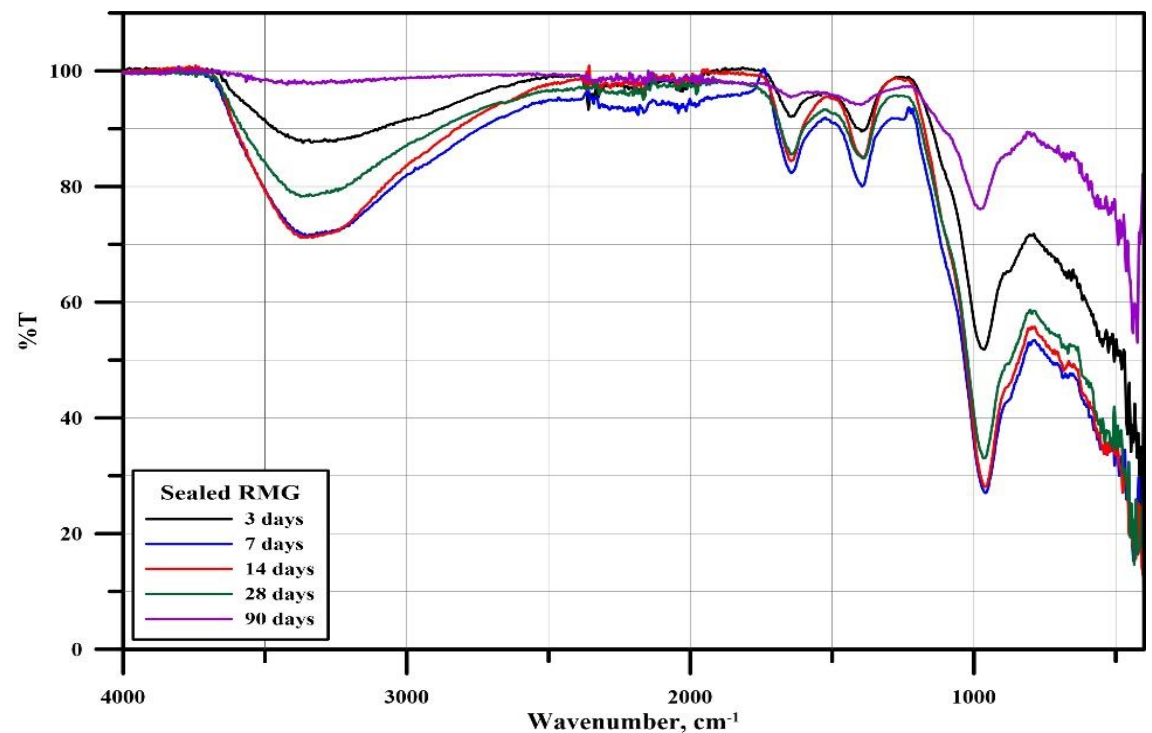

Figure 4. The FT-IR spectra of the non-calcined sealed RMG samples

As it can be observed in Fig. 4, the peak intensities of the non-calcined sealed RMGs increased after the first analysis at the age of 3 days. At 7 and 14 days, the intensities of the peaks associated with the stretching vibrations of the $-\mathrm{OH}$ and $\mathrm{HOH}$ bonds and the asymmetric stretching vibrations of $\mathrm{Si}-\mathrm{O}-\mathrm{Si}$ and 
$\mathrm{Si}-\mathrm{O}-\mathrm{Al}$ bonds followed a similar trend, but the other peak intensities decreased at 14 days. After that, the intensity of every identified peak considerably decreased.

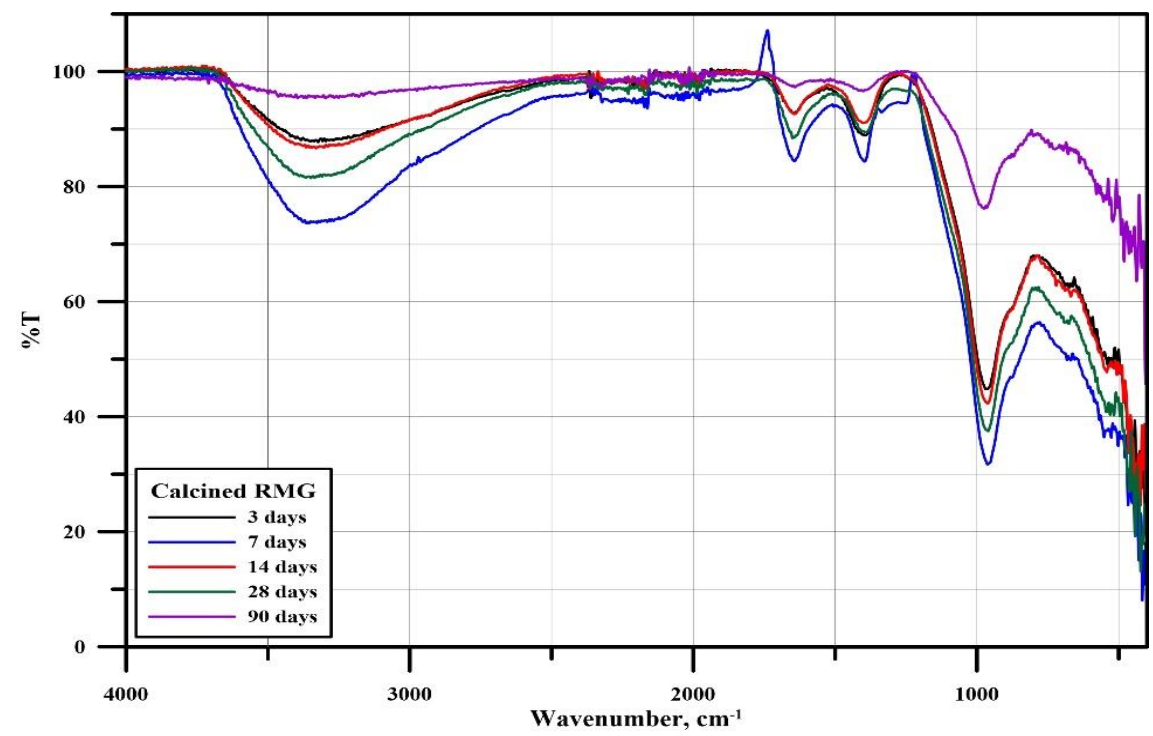

Figure 5. The FT-IR spectra of the calcined sealed RMG samples

The examination of the FT-IR spectra of the calcined sealed RMG samples (Fig.5) revealed no clear trends in relation to the ages of the specimens. The highest peak intensities can be observed after 7 days and the lowest intensities at 90 days. The 3- and 14-day spectra show a similar trend.

Based on the FT-IR analyses it can be stated that by the age of 90 days, the polymerization and polycondensation reactions die down and most of the water is consumed during the different reaction stages.

\section{CONCLUSIONS}

Based on the uniaxial compressive strength tests, it can be concluded that relatively high-strength geopolymer can be made at the age of 7 days from the combination of fly ash from Tatabánya and red mud from Almásfüzitö. However, the cracking of the specimens can be observed when higher amount -20 and 40 wt. $\%$ - RM is added to the mixture. According to the durability tests, the sealing conditions have significant effect on the durability of the specimens. The non-calcined non-sealed geopolymers were fractured after 14 days, and the peak intensities of the FT-IR spectra showed lower intensities than the sealed specimens. When the specimens are sealed, calcination has no noticeable effect on the durability of the geopolymers.

\section{ACKNOWLEDGEMENTS}

The described work/article was carried out as part of the „Sustainable Raw Material Management Thematic Network - RING 2017”, EFOP-3.6.2-16-2017-00010 project in the framework of the Széchenyi2020 Program. The realization of this project is supported by the European Union, co-financed by the European Social Fund. 


\section{REFERENCES}

[1] J. Davidovits, Geopolymers: Inorganic polymeric new materials, Journal of Thermal Analysis, 37 (1991), pp. 1633-1656.

[2] D. Panias, I. P. Giannopoulou, T. Perraki, Effect of synthesis parameters on the mechanical properties of fly ash-based geopolymers, Colloids and Surfaces A: Physicochemical and Engineering Aspects, 301, (2007), pp. 246-254.

[3] J. L. Provis, J. S. J. Van Deventer, Geopolymers - Structures, Processing, Properties and Industrial Applications, CRC Press, Boston, 2009.

[4] S. Yaseri, G. Hajiaghaei, F. Mohammadi, M. Mahdikhani, R. Farokhzad, The role of synthesis parameters on the workability, setting and strength properties of binary binder based geopolymer paste, Construction and Building Materials, 157 (2017), 534-545.

[5] P. Duxon, A. Fernández-Jiménez, J. L. Provis, G. C. Lukey, A. Palomo, J. S. J. Van Deventer, Geopolymer technology: The current state of the art, Journal of Materials Science 42 (2007), pp. 2917-2933.

[6] L. Bokányi, B. Csőke, Á. Debreczeni, L. Gáspár, I. Gombkötő, R. Horváth, Gy. Less, G. Mucsi, Z. Molnár, Á. Rácz, Erőműi pernye komplex hasznosítása, Milagrossa Kft., Miskolc, 2014.

[7] A. Kumar, S. Kumar, Development of paving blocks from synergistic use of red mud and fly ash using geopolymerization. Construction and Building Materials 38 (2013), pp. 865-871.

[8] M. K. Sahu, R. K. Patel, Methods for Utilization of Red Mud and Its Management. In: M. N. V. Prasad, K. Shih (ed.) (2016): Environmental Materials and Waste - Resource Recovery and Pollution Prevention, Elsevier Inc., London, 2016, pp. 484-524.

[9] G. Mucsi, R. Szabó, M. Ambrus, B. Kovács, The Effect of Water Glass Addition on the Mechanical Properties of Fly Ash-Based Geopolymers, In: Füleky György (ed.), XIV. Kárpát-medencei Környezettudományi Konferencia, Gödöllö, Magyarország, April 5-7 2018, pp. 7-12.

[10] H. Choo, S. Lim, W. Lee, C. Lee, Compressive strength of one-part alkali activated fly ash using red mud as alkali supplier, Construction and Building Materials 125 (2016), pp. 21-28.

[11]N. Ye, Y. Chen, J. Yang, S. Liang, Y. Hu, B. Xiao, Q. Huang, Y. Shi, J. Hu, X. Wu, Co-disposal of MSWI fly ash and Bayer red mud using an one-part geopolymeric system, Journal of Hazardous Materials 318 (2016), 70-78.

[12] S. Pişkin, A. K. Figen, E. Özkan, Ü. Özçay, Structural Characterization of Seydişehir Red Mud to Utilization in Roof Tile Manufacturing. IFAC Proceedings Volumes 46 (16) (2013), pp. 484-487.

[13]E. Bonet-Martínez, L. Pérez-Villarejo, D. Eliche-Quesada, B. Carrasco Hurtado, S. Bueno-Rodríguez, E. Castro-Galiano, Inorganic polymers synthesized using biomass ashes-red mud as precursors based on clay-kaolinite system, Materials Letters (2018), doi: https://doi.org/10.1016/j.matlet.2018.05.012.

[14] G. Mucsi, Á. Szenczi, Z. Molnár, J. Lakatos, Structural formation and leaching behavior of mechanically activated lignite fly ash based geopolymer, Journal of Environmental Engineering and Landscape Management. 24 (1) (2016), pp. 48-59. 